\title{
Analisis Pengaruh Perubahan Arus Eksitasi Terhadap Karakteristik Generator (Aplikasi Laboratorium Mesin-Mesin Listrik Fakultas Teknik-Umsu)
}

\author{
Rimbawati, Partaonan Harahap, Kiki Utama Putra \\ Program Studi Teknik Elektro, Fakultas Teknik \\ Universitas Muhammadiyah Sumatera Utara (UMSU) \\ Jl. Kapten Muchtar Basri,BA No. 03 Medan Telp. (061) 6622400 ex. 12 Kode pos 20238 \\ e-mail: rimbawati@umsu.ac.id
}

\begin{abstract}
Abstrak - Pembebanan sistem interkoneksi selalu berubah-ubah setiap saat. Perubahan beban menyebabkan fluktuasi perubahan tegangan keluaran generator dan perubahan pada arus eksitasi generator. Untuk menghasilkan tegangan keluaran generator yang konstan diperlukan suatu pengaturan tegangan keluaran generator. Pengaturan tegangan tersebut dilakukan dengan mengatur arus eksitasinya. Arus eksitasi adalah sistem pasokan listrik DC sebagai penguatan pada generator atau sebagai pembangkit medan sehingga suatu generator dapat menghasilkan energi listrik dengan besar tegangan keluaran generator bergantung pada besarnya arus eksitasi. Pada penelitian ini menggunakan catu daya DC sebagai arus eksiternya dengan nilai yang bervariasi. Hal ini dilakukan untuk mengetahui karakteristik dari generator terhadap perubahan nilai arus eksitasi yang diberikan. Daya reaktif paling tinggi beban R-L dicapai pada pengaturan arus eksitasi sebesar 3,5 ampere dengan nilai daya reaktif sebesar 661,4 var. Sedangkan pada beban R-C daya reaktif yang dihasilkan lebih rendah dari beban R-L yaitu sebesar 616,93 var. Penelitian ini menyimpulkan bahwa tegangan generator sangat dipengaruhi oleh besar kecilnya arus eksitasi yang diberikan. Semakin besar arus eksitasi yang diberikan maka tegangan keluaran generator akan semakin besar. Hal ini berbanding lurus antara tegangan keluaran generator dengan arus eksitasi yang diberikan. Selain itu, pada pembebanan R-L dan R-C daya reaktif yang dihasilkan juga akan bertambah besar.
\end{abstract}

Kata kunci : Arus eksitasi, tegangan generator, daya reaktif

Abstract - The interconnection system loading is always changing. Changes in load cause fluctuations in changes in generator output voltage and changes in generator excitation currents. To produce a constant generator output voltage a regulation of the generator output voltage is required. The voltage regulation is done by adjusting the current excitation. Excitation current is a DC power supply system as a reinforcement to a generator or as a field generator so that a generator can produce electrical energy with a large generator output voltage depending on the amount of excitation current. In this study, DC power supplies are used as exciter current with varying values. This is done to determine the characteristics of the generator to change the value of the given excitation current. The highest reactive power of the $R-L$ load is achieved at the regulation of the excitation current of 3.5 amperes with a reactive power value of 661.4 var. Whereas at the $R-C$ load the reactive power produced is lower than the $R$-L load that is equal to 616.93 var. This study concludes that the generator voltage is strongly influenced by the size of the given excitation current. The greater the excitation current given, the greater the generator output voltage. This is directly proportional between the generator output voltage and the given excitation current. In addition, the loading of $R-L$ and $R-C$ reactive power generated will also increase.

Keywords : Excitation current, generator voltage, reactive power

\section{PENDAHULUAN}

Seiring dengan perkembangan teknologi yang semakin meningkat, kebutuhan akan tenaga listrik setiap hari juga semakin meningkat. Sehingga mendorong peningka-tan penyediaan pembangkit energi listrik yang memadai. Generator merupakan salah satu peralatan utama dalam suatu pembangkit tenaga listrik, baik pada pembangkit listrik tenaga air, pembangkit listrik tenaga gas, pembangkit listrik tenaga uap, dan pembangkit listrik tenaga diesel.
Generator merupakan jenis mesin listrik yang digunakan sebagai alat pembangkit energi listrik dengan cara mengkonversikan energi mekanik menjadi energi listrik. Generator mempunyai kumparan jangkar pada rotor dan kumparan medan pada stator. Apabila kumparan jangkar dihubungkan dengan sumber tegangan tiga fasa akan ditimbulkan medan putar pada stator. Kumparan medan rotor diberi arus searah sehingga mendapatkan tarikan dari kutub medan stator hingga turut berputar dengan 
kecepatan yang sama sampai menimbulkan energi listrik (A.C. Putra, 2018).

Pembebanan sistem interkoneksi selalu berubah-ubah setiap saat. Perubahan beban menyebabkan fluktuasi tegangan keluaran generator. Perubahan tegangan keluaran bisa menimbulkan bermacam-macam efek ke generator. Untuk menghasilkan tegangan keluaran generator yang konstan diperlukan suatu pengaturan tegangan keluaran generator. Pengaturan tegangan tersebut dilakukan dengan mengatur arus eksitasinya. Arus eksitasi adalah sistem pasokan listrik DC sebagai penguatan pada generator atau sebagai pembangkit medan sehingga suatu generator dapat menghasilkan energi listrik dengan besar tegangan keluaran generator bergantung pada besarnya arus eksitasi. Pengaturan arus eksitasi ini akan mempengaruhi tegangan terminal (tegangan keluaran) generator. Arus eksitasi yang tidak dikendalikan akan menyebabkan distribusi fluks menjadi tidak merata (S. Rudi,2 012).

\section{TINJAUAN PUSTAKA}

Generator Sinkron

Dalam sebuah pembangkit tenaga listrik terdapat berbagai macam alat yang di gunakan. Salah satu komponen utama yang di perlukan yaitu generator. Generator sinkron (sering disebut alternator) adalah mesin listrik arus bolak-balik yang menghasilkan tegangan dan arus bolak balik yang bekerja dengan cara mengubah energi mekanik menjadi energi listrik dengan adanya induksi medan magnet (Armansyah, 2016).

\section{Prinsip Kerja Generator Sinkron}

Suatu mesin listrik dapat bekerja apabila memiliki kumparan medan yang akan menghasilkan medan magnet, kumparan jangkar yang berfungsi untuk menyalurkan GGL pada konduktor yang berada pada jalur-jalur jangkar, serta memiliki celah udara yang memungkinkan berputarnya jangkar dalam medan magnet (Laksono, Revan, \& Rabirahim, 2014).

\section{Karakteristik Generator}

Dalam mesin listrik ada dua kurva karakteristik yang digunakan untuk menentukan parameter mesin. Yaitu karakteristik open circuit dan karakteristik hubung singkat (short circuit).

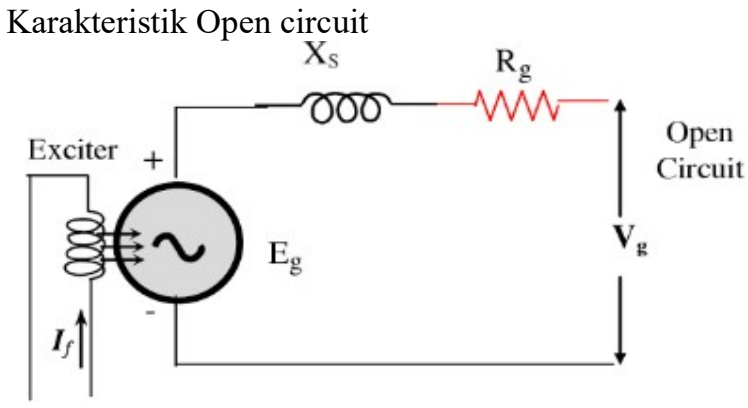

Gambar 1. Rangkaian generator pada kondisi Open Circuit.

Dengan memperbesar arus medan exciter hingga If tertentu maka tengan terminal akan nail dari nol bertambah secara linear, sampai pada suatu titik arus eksitasi terjadi perubahan arah tegangan yang tidak lagi linear dan menuju suatu kondisi yang stasioner atau kondisi jenuh kemudian ketika If terus dinaikkan hingga pada titik tertentu maka tegangan tidak lagi mengalami perubahan harga atau konstan

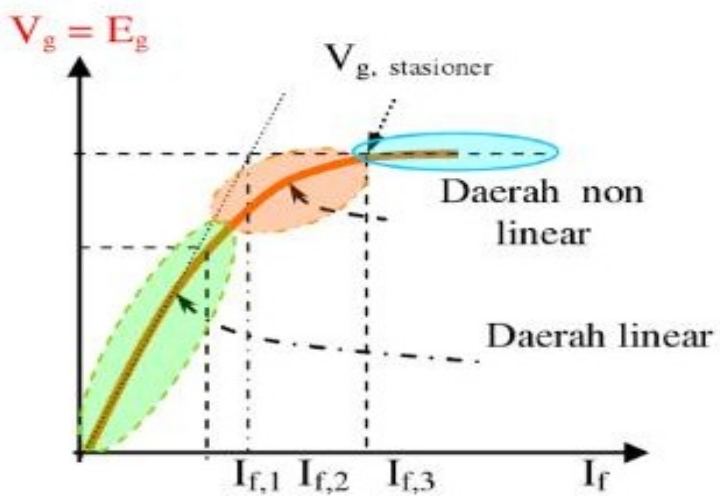

Gambar 2 Kurva Vg terhadap If pada kondisi Open Circuit

Karakteristik Hubung Singkat

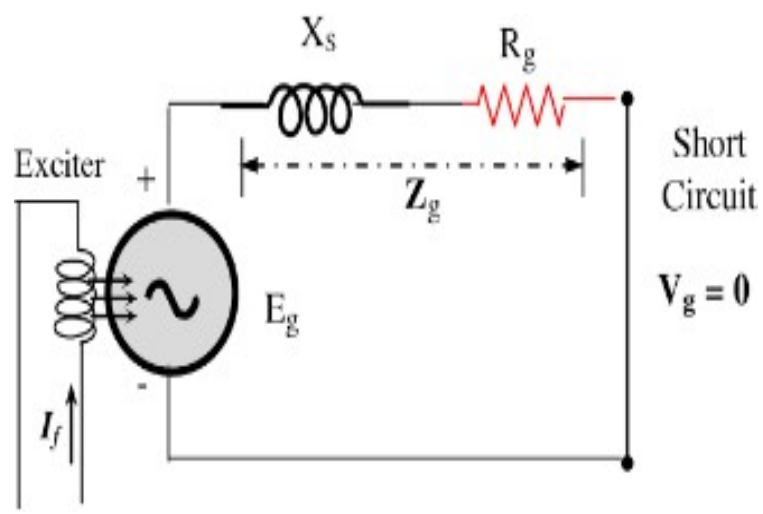

Gambar 3 Rangkaian generator pada kondisi Hubung Singkat. 


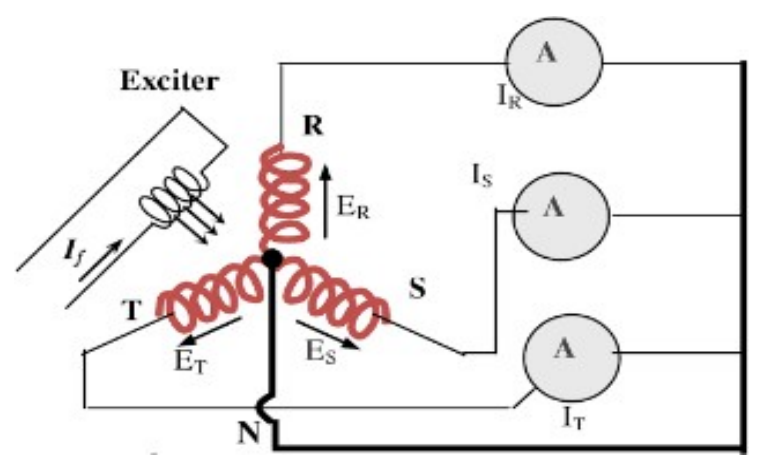

Gambar 4 Rangkaian generator pada kondisi Hubung Singkat $3 ø$

Karakteristik hubung singkat merupakan penggambaran dari hubungan antara arus fasa hubung singkat sebagai fungsi arus medan, dimana ketiga fasa generator dihubung singkat dengan kecepatan putar yang konstan.

Dari persamaan umum generator diperoleh :

$$
\mathrm{Ea}=\mathrm{Vg}+\operatorname{Ig}(\mathrm{Rg}+\mathrm{jXs}) .
$$

Karena generator dalam keadaan hubung singkat, nilai tegangan terminalnya menjadi nol, sehingga :

$$
\mathrm{Ea}=\operatorname{Ig}(\mathrm{Rg}+\mathrm{jXs})
$$

Pada kondisi ini $(\mathrm{Rg}+\mathrm{jXs})$ adalah konstan $=\mathrm{K} 2$, dan $\mathrm{Ig}=$ His, sehingga :

$$
\begin{aligned}
& \text { KIIf }=\text { IhsK } 2 \ldots \ldots . . \\
& \text { Ihs }=\text { K1/K2 (If)... }
\end{aligned}
$$

Dari persamaan di atas, pengukuran hubung singkat berdasarkan penambahan arus medan dari kondisi nol hingga batas yang diperlukan . karakteristik hubung singkat dapat dilihat pada gambar berikut.

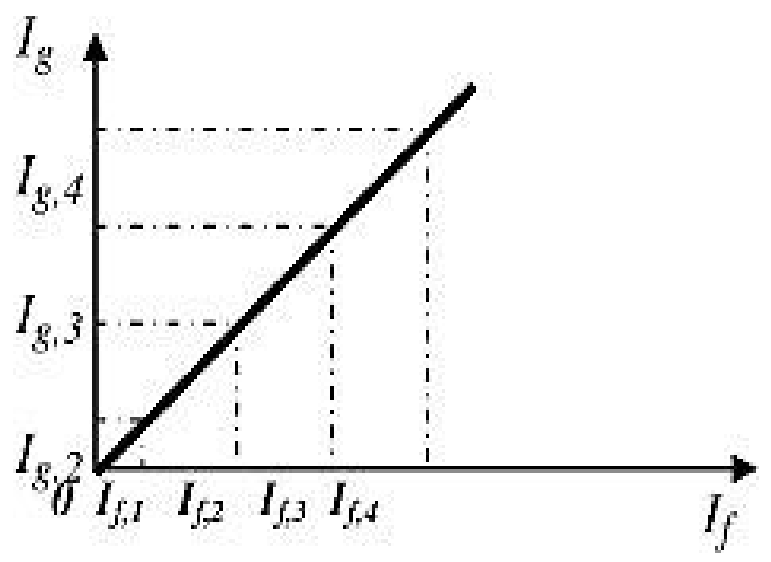

Gambar 5 Karakteristik Pada Kondisi hubung Singkat

\section{Sistem Eksitasi Pada Generator}

Sistem eksitasi merupakan suatu sistem penguatan yang terdapat pada generator, dengan cara memberikan arus penguat pada kumparan medan generator yang muncul karena adanya medan magnet yang disebabkan oleh bantuan arus searah. Arus eksitasi sendiri adalah suatu arus yang diberikan pada kutub magnetik dengan mengatur besar kecil dari nilai arus eksitasi tersebut maka dapat memperoleh nilai tegangan output generator yang diinginkan serta daya reaktifnya (Supardi, 2014). Sistem eksitasi dibagi menjadi dua tipe yaitu sistem eksitasi dengan brush dan tanpa brush.

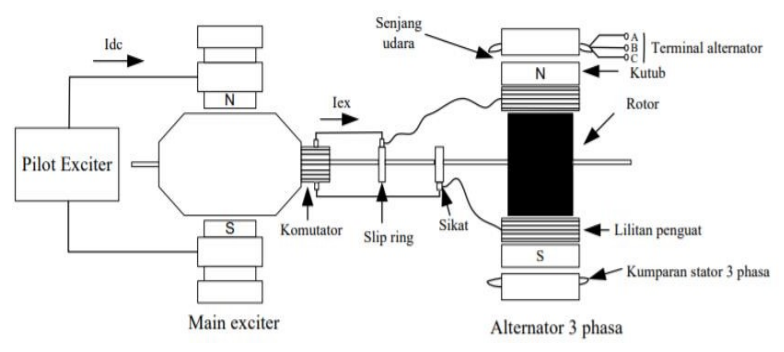

Gambar 6 Sistem Eksitasi dengan Brush

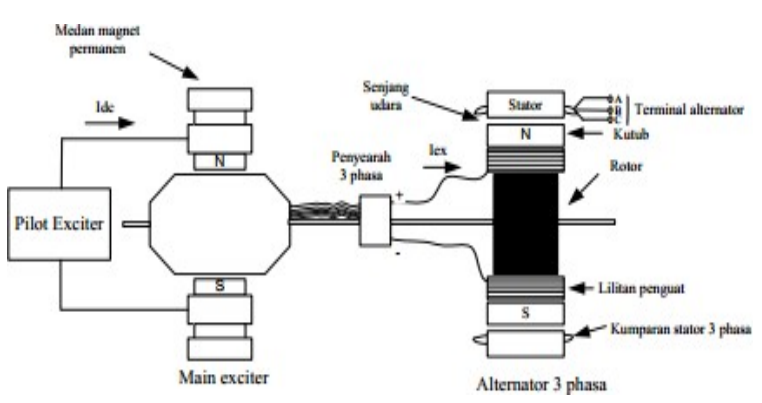

Gambar 7 Sistem Eksitasi Tanpa Brush

Efek Pengaturan Eksitasi Pada Generator Sinkron

$$
\mathrm{E}=\mathrm{Cn} \phi
$$

Keterangan :

$$
\begin{aligned}
& \mathrm{E}=\text { Tegangan induksi (volt) } \\
& \varnothing=\text { Fluks magnetic (weber) } \\
& \mathrm{n}=\text { Putaran (rpm) } \\
& \mathrm{C}=\text { Konstanta }
\end{aligned}
$$

Arus eksitasi yang diatur pada generator yang bekerja dimana kondisi dari putaran tetap maka nilai dari fluks magnetik akan naik serta daya reaktif yang dibutuhkan juga akan mengalami kenaikkan namun nilai dari daya reaktif yang tidak akan berubah sehingga akan mempengaruhi nilai dari faktor daya.

\section{Daya Generator}

Daya listrik didefinisikan sebagai kecepatan aliran energi listrik pada satu titik jaringan listrik tiap satu satuan waktu. Dengan satuan watt atau joule per detik dalam SI, daya listrik menjadi besaran terukur 
adanya produksi energi listrik oleh pembangkit, maupun adanya penyerapan energi listrik oleh beban listrik.

Berdasarkan kesepakatan universal, daya listrik yang mengalir dari rangkaian masuk ke komponen listrik bernilai positif. Sedangkan daya listrik yang masuk ke rangkaian listrik dan berasal dari komponen listrik, maka daya tersebut bernilai negatif (Munarto, 2016).

Daya Semu

Daya semu dikatakan daya total dari kapasitas daya maksimal generator atau diartikan sebagai penjumlahan daya aktif dan daya reaktif.

$$
\begin{aligned}
& \mathrm{S}=\mathrm{V} \times \mathrm{I}(\mathrm{VA}) \text { (satu fasa)...........(6) } \\
& \mathrm{S}=\sqrt{3} \times \mathrm{V} \times \mathrm{I}(\mathrm{VA}) \text { (tiga fasa)...(7) } \\
& \text { Atau } \mathrm{S}=\sqrt{P^{2}+Q^{2}} \ldots \ldots \ldots \ldots \ldots \ldots \ldots(8)
\end{aligned}
$$

Dimana: $\quad \mathrm{V}=$ Tegangan $(\mathrm{V})$

$$
\begin{aligned}
& \mathrm{I}=\operatorname{Arus}(\mathrm{A}) \\
& \mathrm{P}=\text { Daya Aktif } \\
& \mathrm{Q}=\text { Daya Reaktif }
\end{aligned}
$$

\section{Daya Aktif}

Daya aktif sering disebut daya nyata yang memiliki satuan Watt dan merupakan daya yang terpakai untuk melakukan energi sebenarnya. Daya ini sering digunakan secara umum oleh konsumen dan sebagai satuan yang digunakan untuk daya listrik dan dikonversikan dalam bentuk kerja. Dimana dalam perhitungan phasa yaitu :

$$
\begin{aligned}
& \mathrm{P}=\mathrm{V} \times \mathrm{I} \times \operatorname{Cos} \varnothing(\text { satu fasa)........(9) } \\
& \mathrm{P}=\sqrt{ } 3 \times \mathrm{V} \times \mathrm{I} \times \operatorname{Cos} \varnothing(\text { tiga fasa)..(10) }
\end{aligned}
$$

\section{Daya Reaktif}

Daya reaktif dengan satuan Volt Ampere Reactive (VAR), merupakan daya yang disuplay oleh komponen reaktif, atau disebut juga jumlah daya yang diperlukan untuk pembentukan medan magnet. Dari pembentukan medan magnet tersebut akan terbentuk fluks-fluks magnet. Dimana dalam perhitungan phasa yaitu :

$$
\begin{aligned}
& Q=V \times I \times \operatorname{Sin} \varnothing(\text { satu fasa)..........(11) } \\
& Q=\sqrt{ } 3 \times \text { V x I x Sinø (tiga fasa)..(12) }
\end{aligned}
$$

\section{METODE}

Tempat Penelitian

Lokasi penelitian ini dilaksanankan di laboratorium mesin-mesin listrik program studi teknik elektro fakultas teknik universitas muhammadiyah sumatera utara.

Alat dan Bahan Penelitian

Alat dan bahan yang digunakan dalam penelitian ini adalah sebagai berikut :

1. Power supply $0-250 \mathrm{Vdc}$

2. Kit generator

3. Motor induksi

4. Kit beban RLC

5. Multimeter

6. Tang amper

7. Trainer kit Star-Delta

\section{Pengujian Tanpa Beban}

Pengujian yang dilakukan pada penelitian ini yaitu pengujian beban nol dengan mengatur arus eksitasinya. Pengujian pengaruh perubahan arus eksitasi terhadap tegangan keluaran generator dilakukan dengan metode seperti ditampilkan pada gambar berikut

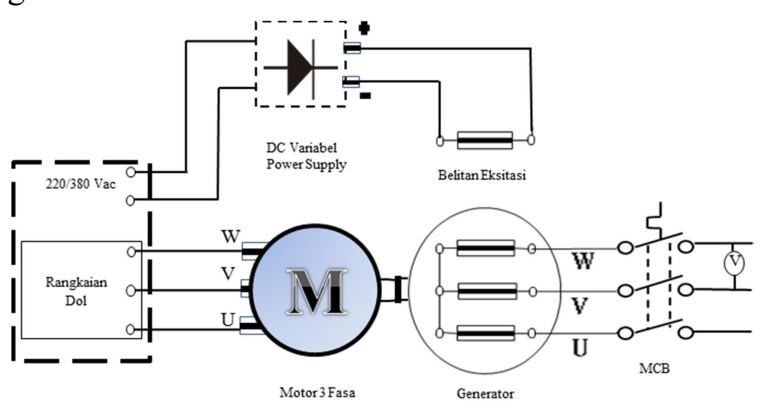

Gambar 8 Rangkaian pengujian tanpa beban

Pada penelitian ini menggunakan DC variabel power supply sebagai arus eksitasinya. Power supply tersebut dihubungkan dengan belitan eksitasi generator menggunakan kabel penghubung. Nilai arus eksitasi yang di berikan pada pengujian ini bervariasi yakni sebesar 0,5 ampere sampai dengan 3,5 ampere. Setelah pengujian dilakukan dilanjutkan dengan melakukan pengukuran. Adapun yang diukur pada pengujian ini yakni mengukur tegangan output generator. Alat yang digunakan dalam melakukan pengukuran yakni menggunakan multimeter untuk mengetahui nilai tegangan output generator serta menggunakan tachometer untuk mengetahui jumlah putaran generator. 
Pengujian Beban R-L

Pada pengujian ini menggunakan beban resistif sebesar $102 \mathrm{ohm}$ dan beban induktif sebesar 0,3 henry yang terhubung seri. Metode yang digunakan sama seperti pada pengujian tanpa beban yaitu menggunakan DC variabel power supply sebagai arus eksitasinya. Nilai arus eksitasi yang di berikan pada pengujian ini bervariasi yakni sebesar 0,5 ampere sampai dengan 3,5 ampere. Setelah pengujian dilakukan dilanjutkan dengan melakukan pengukuran. Adapun yang diukur pada pengujian ini yakni mengukur tegangan output generator dan arus beban pada keadaan berbeban R-L. Setelah didapatkan data pengukuran tegangan keluaran generator dan arus beban, maka dapat dihitung besar daya reaktif generator pada beban R-L.

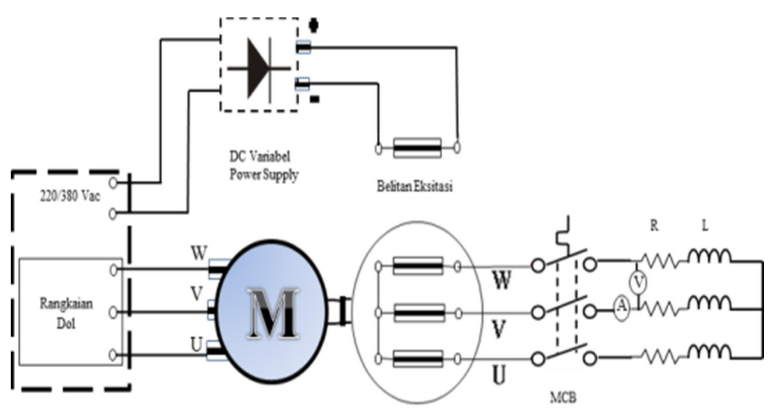

Gambar 9 Rangkaian pengujian beban R-L

Pengujian Beban R-C

Pada pengujian beban R-C menggunakan beban resistif sebesar $102 \mathrm{ohm}$ dan beban capasitif sebesar 50 uf yang terhubung seri. Metode yang dilakukan pada pengujian ini sama seperti pada pengujian tanpa beban dan beban R-L yakni menggunakan DC variabel power supply serta nilai arus eksitasi yang diberikan juga sama pada pengujian tersebut. Pengukuran yang dilakukan yaitu mengukur tegangan output generator dan arus beban R-C. Setelah didapatkan data pengukuran tegangan keluaran generator dan arus beban, maka dapat dihitung besar daya reaktif generator pada beban R-C.

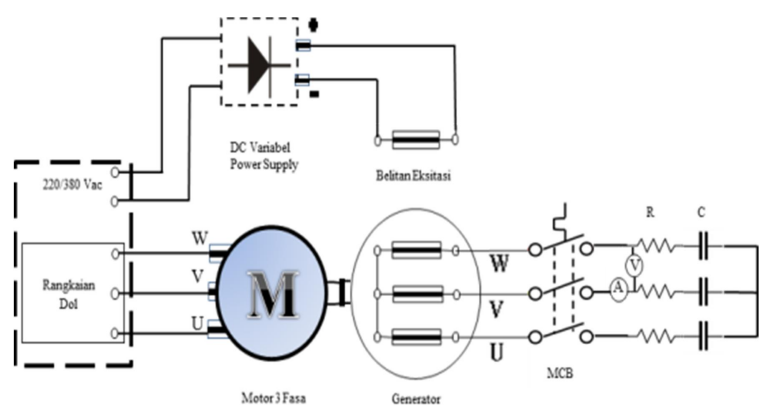

Gambar 10 Rangkaian pengujian beban R-C

\section{HASIL DAN PEMBAHASAN}

Generator Tanpa Beban

Tabel 1. Hasil pengujian karakteristik generator tanpa beban

\begin{tabular}{|c|c|c|c|c|}
\hline Rpm & $\begin{array}{c}\text { If } \\
\text { (A) }\end{array}$ & $\begin{array}{c}\text { Fluxs } \\
\text { m-Wb }\end{array}$ & $\begin{array}{c}\text { V Out } \\
\text { Pengukuran }\end{array}$ & $\begin{array}{c}\text { V Out } \\
\text { Perhitungan }\end{array}$ \\
\hline 1500 & 0,5 & 6,0 & 82,9 & 66,6 \\
\hline 1500 & 1 & 14,0 & 161,4 & 155,4 \\
\hline 1500 & 1,5 & 20,0 & 228,2 & 222 \\
\hline 1500 & 2 & 25,0 & 278 & 277,5 \\
\hline 1459 & 2,5 & 28,0 & 310,2 & 302,3 \\
\hline 1455 & 3 & 31,0 & 332,6 & 332,63 \\
\hline 1450 & 3,5 & 34,0 & 359,8 & 364,82 \\
\hline
\end{tabular}

Berdasarkan hasil perhitungan dan pengukuran pada tabel di atas diperoleh hubungan grafik antara arus eksitasi dengan $\mathrm{v}$ out seperti pada gambar berikut

\section{Arus eksitasi terhadap tegangan} generator

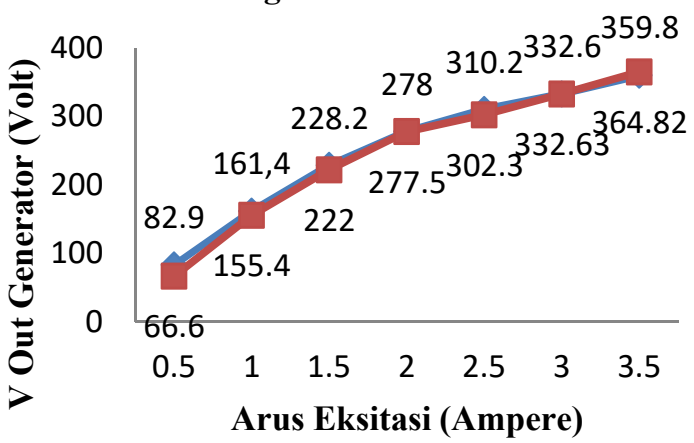

$\sim$ Hasil Pengukuran - Hasil Perhitungan

Gambar 11 Grafik karakterisitk perubahan arus eksitasi terhadap V out generator tanpa beban

Gambar kurva grafik menunjukkan perbedaan tegangan generator pada setiap pengukuran dan perhitungan yang dilakukan. Pada saat pengukuran dengan pengaturan arus eksitasi 0,5 A serta fluksi magnetik sebesar 6 m-weber didapatkan tegangan sebesar 82,9 volt, sedangkan pada perhitungan tegangan sebesar 66,6 volt dan tegangan tersebut memiliki selisih sekitar 16,3 volt. Hal ini disebabkan karena alat ukur yang tidak presisi 
sehingga pembacaan alat ukur tidak teliti.

Generator beban R-L

Tabel 2. Hasil pengujian karakteristik generator beban R-L

\begin{tabular}{|c|c|c|c|c|}
\hline Rpm & $\begin{array}{c}\text { If } \\
\text { (A) }\end{array}$ & $\begin{array}{c}\text { Ia } \\
\text { (A) }\end{array}$ & $\begin{array}{c}\text { V Out } \\
\text { Pengukuran }\end{array}$ & $\begin{array}{c}\text { V Out } \\
\text { Perhitungan }\end{array}$ \\
\hline 1494 & 0,5 & 0,56 & 80,2 & 77,75 \\
\hline 1494 & 1 & 1,05 & 150,8 & 145,78 \\
\hline 1494 & 1,5 & 1,57 & 223,4 & 217,98 \\
\hline 1494 & 2 & 1,93 & 271,2 & 267,96 \\
\hline 1459 & 2,5 & 2,03 & 288,2 & 281,84 \\
\hline 1455 & 3 & 2,15 & 304,8 & 298,5 \\
\hline 1450 & 3,5 & 2,27 & 321,4 & 315,16 \\
\hline
\end{tabular}

Berdasarkan hasil perhitungan dan pengukuran pada tabel diatas diperoleh hubungan grafik antara arus eksitasi dengan $\mathrm{v}$ out seperti pada gambar berikut

\section{Arus eksitasi terhadap Tegangan generator}

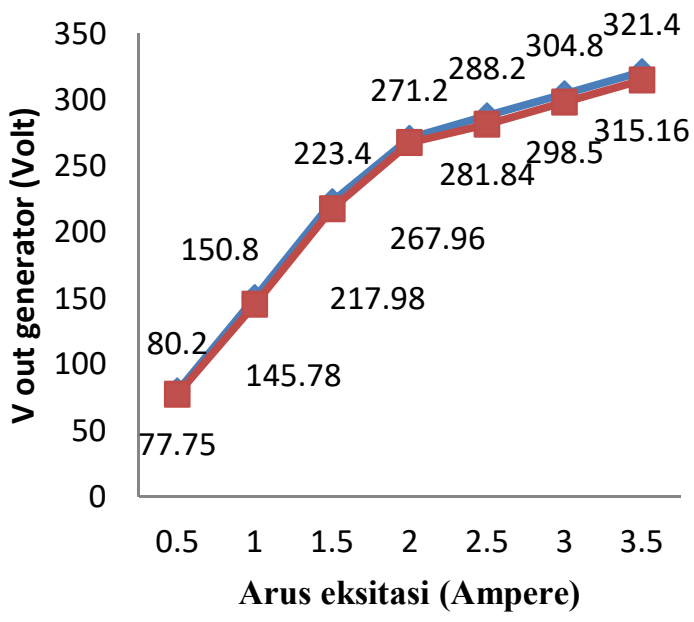

\section{Hasil pengukuran - Hasil perhitungan}

Gambar 12 Grafik karakterisitk perubahan arus eksitasi terhadap V out generator beban R-L

Gambar kurva grafik menunjukkan perbedaan tegangan generator pada setiap pengukuran dan perhitungan yang dilakukan. Pada saat pengukuran dengan pengaturan arus eksitasi 0,5 A didapatkan tegangan sebesar 80,2 volt, sedangkan pada perhitungan tegangan sebesar 77,75 volt dan tegangan tersebut memiliki selisih sekitar 2,45 volt.
Hal ini disebabkan karena alat ukur yang tidak presisi sehingga pembacaan alat ukur tidak teliti.

Generator Beban R-C

Tabel 3. Hasil pengujian karakteristik generator beban R-C

\begin{tabular}{|c|c|c|c|c|}
\hline Rpm & $\begin{array}{c}\text { If } \\
\text { (A) }\end{array}$ & $\begin{array}{c}\text { Ia } \\
\text { (A) }\end{array}$ & $\begin{array}{c}\text { V Out } \\
\text { Pengukuran }\end{array}$ & $\begin{array}{c}\text { V Out } \\
\text { Perhitungan }\end{array}$ \\
\hline 1494 & 0,5 & 0,58 & 73,2 & 69,7 \\
\hline 1494 & 1 & 1,07 & 131,8 & 128,61 \\
\hline 1494 & 1,5 & 1,6 & 196,2 & 192,32 \\
\hline 1494 & 2 & 2,04 & 246,5 & 245,2 \\
\hline 1459 & 2,5 & 2,10 & 258,4 & 252,42 \\
\hline 1455 & 3 & 2,18 & 272,2 & 262 \\
\hline 1450 & 3,5 & 2,33 & 289,8 & 280 \\
\hline
\end{tabular}

Berdasarkan hasil perhitungan dan pengukuran pada tabel di atas diperoleh hubungan grafik antara arus eksitasi dengan $\mathrm{v}$ out seperti pada gambar berikut

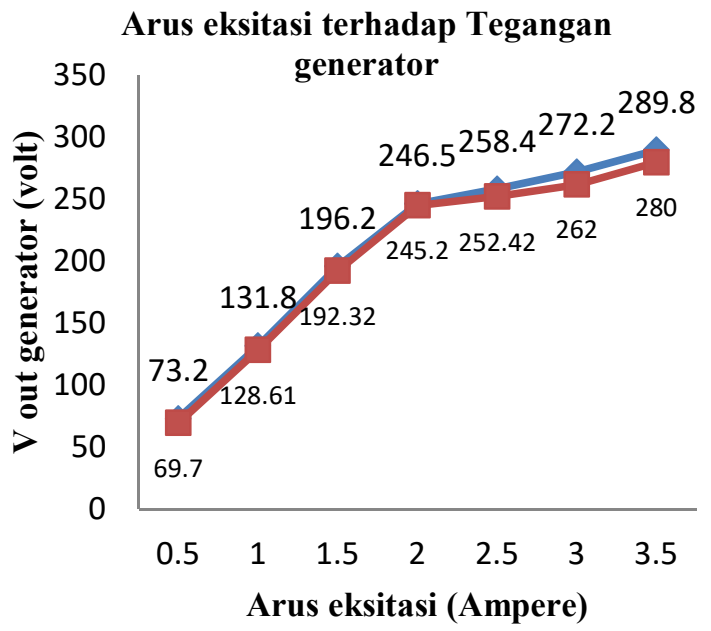

$\longrightarrow$ Hasil pengukuran $\_$Hasil perhitungan

Gambar 13 Grafik karakterisitk perubahan arus eksitasi terhadap V out generator beban R-C

Gambar kurva grafik menunjukkan perbedaan tegangan generator pada setiap pengukuran dan perhitungan yang dilakukan. Pada saat pengukuran dengan pengaturan arus eksitasi 0,5 A didapatkan tegangan sebesar 73,2 volt, sedangkan pada perhitungan tegangan sebesar 69,7 volt dan 
tegangan tersebut memiliki selisih sekitar 3,5 volt. Hal ini disebabkan karena alat ukur yang tidak presisi sehingga pembacaan alat ukur tidak teliti.

Daya Reaktif Generator beban R-L

Tabel 4. Hasil perhitungan daya reaktif generator beban R-L

\begin{tabular}{|c|c|c|c|c|}
\hline Rpm & $\begin{array}{c}\text { If } \\
(\mathrm{A})\end{array}$ & $\begin{array}{c}\text { Ia } \\
(\mathrm{A})\end{array}$ & $\begin{array}{c}\text { V Out } \\
\text { (Volt) }\end{array}$ & Q (Var) \\
\hline 1500 & 0,5 & 0,56 & 80,2 & 77,75 \\
\hline 1500 & 1 & 1,05 & 160,8 & 145,78 \\
\hline 1500 & 1,5 & 1,57 & 223,4 & 217,98 \\
\hline 1500 & 2 & 1,93 & 277,2 & 267,96 \\
\hline 1459 & 2,5 & 2,03 & 308,2 & 281,84 \\
\hline 1455 & 3 & 2,15 & 328,9 & 298,5 \\
\hline 1450 & 3,5 & 2,27 & 355,4 & 315,16 \\
\hline
\end{tabular}

Berdasarkan hasil perhitungan pada tabel di atas diperoleh hubungan grafik antara arus eksitasi dengan daya reatif seperti pada gambar berikut

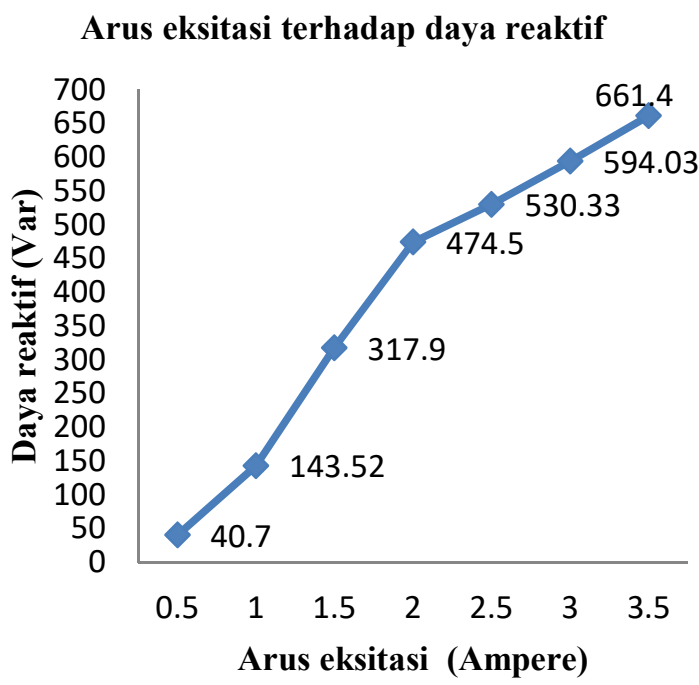

Gambar 14 Grafik karakterisitk perubahan arus eksitasi terhadap daya reaktif generator beban R-L

Berdasarkan gambar di atas dapat dilihat perubahan nilai daya reaktif yang diperoleh pada beban R-L dengan pengaturan arus eksitai yang berbeda-beda. Daya reaktif pada pengaturan arus eksitasi 1,5 A mengalami kenaikkan yang cukup signifikan yakni sebesar 178,38 Var.
Daya Reaktif Generator beban R-C

Tabel 5. Hasil perhitungan daya reaktif generator beban $\mathrm{R}-\mathrm{C}$

\begin{tabular}{|c|c|c|c|c|}
\hline R-C & $\begin{array}{c}\text { If } \\
\text { (A) }\end{array}$ & $\begin{array}{c}\text { Ia } \\
\text { (A) }\end{array}$ & $\begin{array}{c}\text { V Out } \\
\text { (Volt) }\end{array}$ & $\begin{array}{c}\text { Q } \\
\text { (Var) }\end{array}$ \\
\hline 1500 & 0,5 & 0,58 & 73,2 & 38,8 \\
\hline 1500 & 1 & 1,07 & 131,8 & 128,85 \\
\hline 1500 & 1,5 & 1,6 & 196,2 & 286,82 \\
\hline 1500 & 2 & 2,04 & 246,5 & 459,45 \\
\hline 1459 & 2,5 & 2,10 & 258,4 & 495,8 \\
\hline 1455 & 3 & 2,18 & 272,2 & 542,16 \\
\hline 1450 & 3,5 & 2,33 & 289,8 & 616,93 \\
\hline
\end{tabular}

Berdasarkan hasil perhitungan pada tabel di atas diperoleh hubungan grafik antara arus eksitasi dengan daya reatif seperti pada gambar berikut

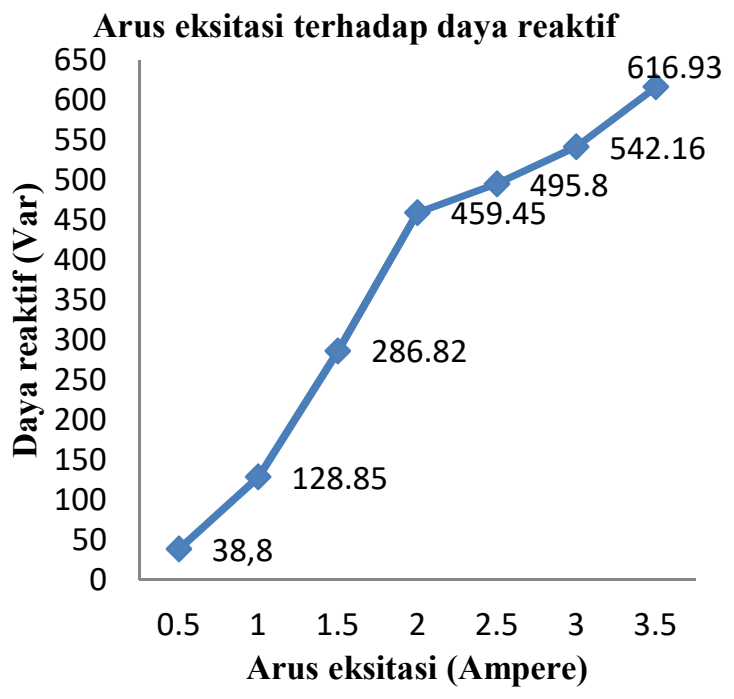

Gambar 15 Grafik karakterisitk perubahan arus eksitasi terhadap daya reaktif generator beban R-C

Berdasarkan gambar di atas dapat dilihat perubahan nilai daya reaktif yang diperoleh pada beban R-C dengan pengaturan arus eksitai yang berbeda-beda. Daya reaktif pada pengaturan arus eksitasi 2,5 A mengalami kenaikkan yang cukup signifikan yakni sebesar 172,63 Var.

\section{KESIMPULAN}

Pengaturan arus eksitasi pada generator mempengaruhi nilai tegangan keluaran generator. Tegangan tersebut sangat dipengaruhi oleh besar kecilnya arus eksitasi yang diberikan. Semakin besar arus eksitasi yang diberikan maka tegangan keluaran generator akan semakin besar. 
Pada beban R-L daya reaktif paling tinggi dicapai pada pengaturan arus eksitasi sebesar 3,5 ampere dengan nilai daya reaktif sebesar 661,4 var. Sedangkan daya reaktif terendah di dapat pada pengaturan arus eksitasi sebesar 0,5 ampere dengan nilai sebesar 40,7 var.

Pada beban R-C tegangan yang dihasilkan dari pengaturan arus eksitasi lebih rendah dari beban R-L sehingga daya reaktif yang dihasilkan juga lebih rendah. Pada beban $\mathrm{R}-\mathrm{C}$ daya reaktif paling tinggi dicapai pada pengaturan arus eksitasi sebesar 3,5 ampere dengan nilai daya reaktif sebesar 616,93 Var. Sedangkan daya reaktif terendah di dapat pada pengaturan arus eksitasi sebesar 0,5 ampere dengan nilai sebesar 38,8 Var.

\section{DAFTAR PUSTAKA}

[1] Rudi, S., "Pengaruh Perubahan Arus Eksitasi Terhadap Tegangan Keluaran Generator Sinkron," vol. 12, no. 2, pp. 85-88, 2012

[2] Nurdin, A., Azis, A., and Rozal, R. A., "Peranan Automatic Voltage Regulator Sebagai Pengendali Tegangan Generator,' vol. 3, no. 1, pp. 163-173, 2018

[3] Ridzki, I., "Analisis Pengaruh Perubahan Eksitasi Terhadap Daya Reaktif generator," vol. 11, no. 2, pp. 31-41, 2013.

[4] Terimananda, R. G. and Hariyanto, N., "Studi Pengaturan Arus Eksitasi untuk Mengatur Tegangan Keluaran Generator di PT Indonesia Power UBP Kamojang Unit 2," vol. 4, no. 1, pp. 51-62, 2016

[5] Laksono, H. D., Haliman, D., Danas, A. and W.D.A, "Analisa Kekokohan Tanggapan Tegangan Sistem Eksitasi Generator Terhadap Perubahan Parameterkonstanta Penguatan Generator dengan Berbagai Pengendali," vol. 13, no. 1, pp. 9-18, 2016

[6] Laksono, H. D., and Febrianda, A., "Analisa Performansi Tanggapan Tegangan Sistem Eksitasi Generator Terhadap Perubahan Parameter," vol. 4, no. 1, pp. 63-3, 2015.

[7] Irnanda, P., “ Analisis Pengaruh Eksitasi Terhadap Efek Harmonisa Pada Hubungan Belitan Generator Sinkron Dengan Beban LHE," vol. 2, no. 1, pp. 40-44, 2012

[8] Laksono, H. D., and Yulianto, N. F., "Evaluasi Pola Tingkah Laku Tegangan sistem Eksitasi Generator Dengan Metoda Penempatan Kutub Menggunakan Algoritma Bass-Gura," vol. 2 no. 2, pp. 18-26, 2013.
[9] Armansyah, S., "Pengaruh Penguatan Medan Generator Sinkron Terhadap Tegangan Terminal," J. Tek. Elektro UISU, vol. 1, no. 3, pp. 48-55, 2016.

[10] Pamungkas, R. C., Mustar, M. Y., and Syahputra, R., "Analytical Studies of the Excitation System of Synchronous Generator in Steam Power Plant Unit 3 and 4 at PJB UP Gresik," vol. 1, no. 3, pp. 148-156, 2017.

[11]Laksono, H. D., Revan, M. and Rabirahim, A., "Pemodelan dan Analisa Sistem Eksitasi Generator," vol. 21, no. 1, pp. 60-69, 2014.

[12] Bandri, S., "Analisa Pengaruh Perubahan Beban Terhadap Karakteristik generator Sinkron ( Aplikasi PLTG Pauh Limo Padang )," vol. 2, no. 1, pp. 42-48, 2013.

[13]Basofi and I.S. Amien, "Studi Pengaruh Arus Eksitasi Pada Generator Sinkron Yang Bekerja Paralel Terhadap Perubahan Faktor Daya," vol. 7, no. 1, pp. 8-15, 2014.

[14] Azhar, M. Kamal, and Subhan, "Penerapan Automatic Voltage Regulator pada Sistem Eksitasi Harmonik Generator Satu Fasa," Seminar Nasional dan Expo Teknik Elektro 2017 Bandah Aceh, 18-19 Oktober 2017

[15] Supardi, A., Prasetya, D.A, and J. Susilo, “ Pengaruh Ukuran Kapasitor Terhadap Karakteristik Keluaran Generator Induksi 1 Fase," Prosiding Seminar Nasional Aplikasi Sains \& Teknologi (SNAST) 2014, Yogyakarta, 15 November 2014, ISSN: 1979-911X, pp. 7178.

[16] Aini, A. N., Eldion, M. B., and Endarko, "Rangkaian RLC Seri Arus AC (E7)," Jurnal Elektronika Dasar II, NRp:1114-094, 2016.

[17] Yani, H., "Studi Penggunaan Komponen RLC Pada Filter Harmonik Tiga Fasa Untuk Perbaikan Kualitas daya Dengan Matlab Simulink," vol. 5, no. 1, pp. 1-6, 2013.

[18] Priyatna, A., Haryanto, H., and R. Munarto, "Pengujian Karakteristik Generator Sinkron Megnet Permanen Sebagai Pembangkit Listrik Tenaga Bayu (PLTB)," The $3^{\text {nd }}$ National conference on Industrial Electrical and Electronics (NCIEE) Proceedings ISBN:978602-98211-0-9, 2016.

[19]Zuhal, "Dasar Teknik Tenaga Listrik Dan Elektronika Daya," Jakarta : PT Gramedia Pustaka Utama, 2000. 